\title{
Human exploitation of male fiddler crab claws: behavioural consequences and implications for conservation
}

\author{
Rui F. Oliveira ${ }^{1}$, José L. Machado ${ }^{1}$, Joana M. Jordão ${ }^{1}$, Fiona L. Burford ${ }^{2}$, Claire Latruffe ${ }^{2}$ \& Peter K. McGregor ${ }^{2}$ \\ ${ }^{1}$ Unidade de Investigação em Eco-Etologia, Instituto Superior de Psicologia Aplicada, Rua Jardim do Tabaco 44, 1100 Lisboa, Portugal \\ ${ }^{2}$ Zoological Institute, University of Copenhagen, Tagensvej 16, 2200 Copenhagen N, Denmark
}

(Received 11 January 1999; accepted 16 April 1999)

\begin{abstract}
Male fiddler crabs have one of their feeding claws greatly enlarged, which may comprise up to $40 \%$ of their weight. In southern Portugal (Ria Formosa) the major claw of the fiddler crab Uca tangeri is a local delicacy. Fishermen break off the male major claw and throw the crab back into the mudflat to regenerate a new one. Approximately $38 \%$ of the males sampled had a missing or a regenerating claw. Although individuals are not removed from the population the operational sex ratio is biased towards females since other males and females behave towards clawless males as if they were females. Moreover, removing the major claw from males prevents them from signalling (waving display) to females to attract them to their breeding burrows and it also places them at a disadvantage if they have to defend their burrows from males with intact claws. Thus, the harvesting of male fiddler crab claws has potential consequences at the population level. In this paper we investigated these potential consequences by comparing an exploited population of fiddler crabs at Ria Formosa with a remote population at the Mira estuary that is not under human exploitation. The unexploited population has significantly larger males and a significantly higher density of burrows. The operational sex ratio is also significantly different between the two populations with a female-biased sex ratio in the exploited population. These preliminary results suggest that claw harvesting in fiddler crabs has a measurable effect at the population level. The consequences of this type of fishery in which the individuals are not removed from the population but the population structure is potentially affected need further investigation.
\end{abstract}

\section{INTRODUCTION}

Fiddler crabs (genus $U c a$ ) are characterized by a great sexual dimorphism in chelae size. While females have small isomorphic claws adapted for feeding on sedimentary grains, male fiddler crabs develop one of their chelae into a major claw which can constitute up to $40 \%$ of male body weight and be up to 30 times larger than the other chelae (Crane, 1975; Rozenberg, 1997). This major claw has lost its function in feeding and is used exclusively for displaying and for fighting behaviour (Crane, 1975; Rozenberg, 1997). Males wave their claws when females are present in order to attract them to their burrows and the claw is also used as a weapon to push other males in territorial disputes (Crane, 1975). Moreover, fiddler crabs use this structure for sex recognition. If a claw is removed from a male, the other males will display towards him as if he was a female and will

All correspondence to: Rui F. Oliveira. Tel: 351-1-8811700; Fax: 351-1-8860954; E-mail: ruiol@ispa.pt. not attack him. On the other hand, if a claw is attached to a female she will be attacked by males (Salmon \& Stout, 1962). Furthermore, different studies have suggested an important role of the enlarged claw size in male mating success both through an advantage in male-male competition over breeding burrows (intrasexual selection) and/or through female mate choice (inter-sexual selection) (Greenspan, 1980; Christy \& Salmon, 1984; Backwell \& Passmore, 1996; Jennions \& Backwell, 1996; Oliveira \& Custódio, 1998). Thus, the major claw is a very important structure for fiddler crab mating behaviour as it influences sex recognition and sexual selection.

In Algarve (south coast of Portugal) the major claw of fiddler crabs is a local delicacy and it is a valuable economic resource for local fishermen (claws are sold for 1500 Portuguese escudos (PTE)/kg compared with $2200 \mathrm{PTE} / \mathrm{kg}$ for sea bass, prices refer to the Summer of $1998 ; 1 \mathrm{US} \$ \cong 178$ PTE). Fisherman catch the males during low tide and the major claw is pulled off and the male is then released on the mudflat. This human 
exploitation of the claws is probably the main selection pressure on the population as predation episodes were seldom observed (pers. obs.; Faria, 1994). The harvesting of male fiddler crab claws is an interesting fishing activity in terms of its consequences for the exploited population since it does not remove individuals from the population but it does affect the structure of the population (e.g. operational sex ratios).

In the estuary of the River Mira near Vila Nova de Milfontes (south-western Portuguese coast) there is a remote population that is not exploited by the local fisherman. This population can therefore be used as a control to study the effects of claw harvesting in the Algarve population.

\section{MATERIALS AND METHODS}

The European fiddler crab, Uca tangeri, was studied at two locations: Ria Formosa Natural Park (south coast of Algarve, Portugal, $36^{\circ} 59^{\prime} \mathrm{N}, 7^{\circ} 51^{\prime} \mathrm{W}$ ) and the Mira estuary (south-western coast of Portugal, $37^{\circ} 40^{\prime} \mathrm{N}, 8^{\circ} 45^{\prime} \mathrm{W}$ ). Ria Formosa is a large lagoon formed by a succession of sand barrier islands that run along the coast and is in permanent connection with the open sea. During lowtide it consists mainly of mudflats and salt marshes. Two study sites were used at Ria Formosa: (1) Marim, which is situated $12 \mathrm{~km}$ east of Faro, and consists of a sandy beach with an average population density of $U$. tangeri of $2.06 / \mathrm{m}^{-2}$ (burrow density); (2) Cacela Velha, which is situated $40 \mathrm{~km}$ east from Faro, and consists of a mudflat with saltmarshes in the upper tidal areas. The Mira estuary is a small tidal estuary located near the village of Vila Nova de Milfontes, with an approximate length of $40 \mathrm{~km}$ and a maximum width of $400 \mathrm{~m}$ near the mouth of the river. The study site in the estuary was located in the mudflat in front of Moinho-da-Asneira. The data from Marim were only used to measure the consistency of the number of clawless males in the population at a given time. To compare the exploited population with an unexploited population we used Cacela and Mira, respectively, because these two areas are similar in terms of sediment characteristics (Andrade, 1986; Lourenço, 1995), which could influence the dependent variables under study (e.g. Ringold, 1979).

To quantify the number of males without claws or with regenerating claws transects were established in each study area (Cacela and Mira). The observer walked along these transects at the peak of low tide and stopped at approximately $20 \mathrm{~m}$ intervals. At each sampling point the observer with the help of binoculars counted the number of males, females and males with or without regenerating claws on both sides of the transect within their field of vision. By leaving the $20 \mathrm{~m}$ interval between sampling points we avoided the same individuals being counted twice. Transects were randomly established in the mudflat and each transect was only done once to avoid pseudo-replication of data.

To compare burrow density $16 \times 1 \mathrm{~m}^{2}$ quadrats were randomly placed in the mudflat at approximately $10 \mathrm{~m}$ intervals along a transect. Within each quadrat all burrow openings were counted and measured to the nearest millimetre using a vernier calliper. Burrow opening diameter was used as an indicator of crab size since a good correlation was found between it and carapace width of the burrow owner $(n=31, r=0.63, P<0.001)$.

\section{RESULTS AND DISCUSSION}

In the two exploited study sites monitored in Ria Formosa up to $38 \%$ of the males had a missing or regenerating major claw (37\% at Cacela and $38.4 \%$ at Marim). To check for the consistency of the number of clawless males counted in the population at a given time, we monitored the population of Marim over a moon cycle during July 1996. There was no significant temporal variation in the number of males with regenerating claws (new moon: $n=71$, males with regenerating claws $=$ $42 \%$; waxing moon: $n=102$, males with regenerating claws $=34.2 \%$; full moon: $n=53$, males with regenerating claws $=35.9 \%$; waning moon: $n=73$, males with regenerating claws $=43.1 \%$; overall: $n=299$, males with regenerating claws $=38.4 \%$ ). Moreover, the percentage of males with regenerating claws does not seem to vary significantly between years (Marim in 1996, $n=299$, males with regenerating claws $=38.4 \%$ versus Marim in $1998, n=150$, males with regenerating claws $=$ $34.6 \%$ ) or among different places (Marim in 1998, $n=150$, males with regenerating claws $=34.6 \%$ versus Cacela in 1998, $n=194$, males with regenerating claws $=37 \%$ ) within Ria Formosa.

Although most males seem to survive claw removal and regenerate their claw (but see Davis et al., 1978), this activity has potentially adverse effects on fiddler crabs at different levels. At the behavioural level, clawless males continue to behave as males, attempting to fight males and to attract females to their burrows for mating by waving their minor claw (or the regenerating claw in the case of males that have started to regenerate their claws), but the other males and females respond to them as if they are females. Males wave at approaching clawless males and do not show the threat display usually employed towards approaching conspecific males. Females are not attracted to the burrows of clawless males. Thus, removing the major chelae prevents males from signalling and from mating. As a consequence operational sex ratio (the number of males ready to mate versus the number of receptive females: Emlen \& Oring, 1977) is predicted to be biased towards females. Operational sex ratio can influence the mechanisms of sexual selection and ultimately the reproductive rate of the population (Emlen \& Oring, 1977; Clutton-Brock \& Parker, 1992). However, the effect of the change in the operational sex ratio on the reproductive rate of the population depends on which sex limits the population. If females are the limiting sex then impairment of males by removing their claws could have no effect on the reproductive rate of the population.

Preliminary results support the suggestion that claw removal has a significant impact on the population (Table 1). The unexploited population at the Mira 
Table 1. Comparison of different population parameters between the exploited (Ria Formosa) and the unexploited (Mira estuary) populations of $U$. tangeri

\begin{tabular}{|c|c|c|c|}
\hline Variable & $\begin{array}{l}\text { Exploited } \\
\text { population } \\
\text { (Ria Formosa) }\end{array}$ & $\begin{array}{l}\text { Unexploited } \\
\text { population } \\
\text { (Mira estuary) }\end{array}$ & Significance \\
\hline $\begin{array}{l}\text { Percentage of } \\
\text { males with } \\
\text { regenerating } \\
\text { claws }\end{array}$ & $\begin{array}{l}37 \% \\
(n=194)\end{array}$ & $\begin{array}{l}0 \% \\
(n=145)\end{array}$ & $P<0.0001^{\dagger}$ \\
\hline $\begin{array}{l}\text { Carapace size } \\
\text { (burrow opening } \\
\text { diameter, mm) }\end{array}$ & $\begin{array}{l}31.9 \pm 6.7 \\
(n=63)\end{array}$ & $\begin{array}{l}37.6 \pm 6.3 \\
(n=30)\end{array}$ & $\begin{array}{l}t=-3.83 \\
P<0.001^{\ddagger}\end{array}$ \\
\hline $\begin{array}{l}\text { Population density } \\
\text { (burrows } / \mathrm{m}^{-2} \text { ) }\end{array}$ & $\begin{array}{l}4.3 \pm 2.1 \\
(n=16)\end{array}$ & $\begin{array}{l}7.2 \pm 3.3 \\
(n=16)\end{array}$ & $\begin{array}{l}t=-2.96 \\
P<0.01^{\ddagger}\end{array}$ \\
\hline $\begin{array}{l}\text { Sex ratio (all males: } \\
\text { females) }\end{array}$ & $\begin{array}{l}1.18 \\
(n=3072)\end{array}$ & $\begin{array}{l}1.22 \\
(n=263)\end{array}$ & $\mathrm{NS}^{\dagger}$ \\
\hline $\begin{array}{l}\text { Operational sex ratio } \\
\text { (males with claws: } \\
\text { females) }\end{array}$ & $\begin{array}{l}0.73 \\
(n=3072)\end{array}$ & $\begin{array}{l}1.22 \\
(n=263)\end{array}$ & $P=0.0001^{\dagger}$ \\
\hline
\end{tabular}

Test of differences between two proportions (Statsoft, 1995)

${ }^{*} t$-test for independent samples.

estuary has both significantly larger males and a significantly higher density of burrows. Moreover, the sex ratio (males : females) in both populations is not significantly different (1.18 at Ria Formosa versus 1.22 at the Mira estuary) but if the number of males with regenerating claws is taken into account in the exploited population and the operational sex ratio is computed, then the sex ratio is significantly female-biased in the Ria Formosa population (Table 1).

These results suggest that males in the exploited population suffer a decrease in body size due to a reallocation of energy from growth into the regeneration of the claw. Limb loss is known to affect crustacean growth and several studies have shown a 'regenerative load' (sensu Skinner, 1985), where the reduction in growth increments at the moult will be proportional to the required regeneration (for a review see Juanes \& Smith, 1995).

Male-biased sex ratios have been measured repeatedly in different species of fiddler crabs (Valiela et al., 1974; Wolf, Shanholtzer \& Reimold, 1975; Ahmed, 1976). Two explanations have been advanced for this finding: (1) differential mortality, assuming that females suffer greater predation than males (Wolf et al., 1975; Bildstein, McDowell \& Brisbin, 1989), or (2) the male bias is an artifact of sample collection. However, the second explanation is more likely because counts of individuals on the surface may bias the sex ratio towards males, since females are known to spend more time inside their burrows than males (Valiela et al., 1974). Regardless of the explanation for male-biased sex ratio in temperate fiddler crabs, we also found such a male preponderance in the unexploited population of $U$. tangeri at the Mira estuary, whereas it is female-biased in the exploited population.

Since a sharp decrease in the population has been detected, the impact of claw removal in the Ria Formosa
Table 2. Temporal variation in population density for the European (southern Spain and Ria Formosa, Portugal) population of U. tangeri

\begin{tabular}{|c|c|c|c|}
\hline Year & Locality & Burrows $/ \mathrm{m}^{-2}$ & Reference \\
\hline 1960 & Cádiz, Spain & 18 & von Hagen, 1962 \\
\hline 1989 & $\begin{array}{l}\text { Ramalhete, Ria } \\
\text { Formosa, Portugal }\end{array}$ & 17 & Wolfrath, 1992 \\
\hline 1994 & $\begin{array}{l}\text { Cacela, Ria Formosa, } \\
\text { Portugal }\end{array}$ & 14 & Lourenço, 1995 \\
\hline 1996 & $\begin{array}{l}\text { Marim, Ria Formosa, } \\
\text { Portugal }\end{array}$ & 2 & $\begin{array}{l}\text { Oliveira, McGregor } \\
\text { et al., } 1998\end{array}$ \\
\hline 1996 & $\begin{array}{l}\text { Cacela, Ria Formosa, } \\
\text { Portugal }\end{array}$ & 5 & $\begin{array}{l}\text { Oliveira, McGregor } \\
\text { et al., } 1998\end{array}$ \\
\hline 1998 & $\begin{array}{l}\text { Marim, Ria Formosa, } \\
\text { Portugal }\end{array}$ & 1 & $\begin{array}{l}\text { Our unpublished } \\
\text { data }\end{array}$ \\
\hline 1998 & $\begin{array}{l}\text { Cacela, Ria Formosa, } \\
\text { Portugal }\end{array}$ & 4 & $\begin{array}{l}\text { Our unpublished } \\
\text { data }\end{array}$ \\
\hline
\end{tabular}

fiddler crabs is potentially more serious. There has been a sharp decrease in the $U$. tangeri population at Ria Formosa over the last two decades (Table 2). Although this type of fishing has been practised for a long time (von Hagen, 1962; local fishermen, pers. comm.), it is likely that the low population density, possibly caused by other reasons (populations of other invertebrate species at the Ria Formosa have also been decreasing in recent years: L. Fonseca, pers. comm.), is now at the level at which the behavioural consequences of claw loss could be enough to drive the population extinct.

If fiddler crabs were to be driven extinct at Ria Formosa this would have serious consequences for mudflat communities. At Ria Formosa fiddler crabs dig out burrows varying between $40 \mathrm{~cm}$ and $90 \mathrm{~cm}$ deep, moving a volume of sediment between 3000 and 6000 $\mathrm{cm}^{3} / \mathrm{m}^{2}$ of mudflat (Wolfrath, 1992). There are several benefits from this activity: (1) it brings material from deeper sediment depths back to the surface, which then becomes involved in the geochemical cycles again (Katz, 1980; Montague, 1982; Wolfrath, 1992); (2) it increases the sediment surface area, hence promoting the exchange of $\mathrm{O}^{2}$ and $\mathrm{CO}^{2}$ between the air and the sediment, and playing an important role in the transport of $\mathrm{O}^{2}$ into deeper sediment layers (Wolfrath, 1992); (3) it enhances the removal of toxic $\mathrm{H}^{2} \mathrm{~S}$ from the sediment (Katz, 1980); (4) it directly increases the mudflat biodiversity by creating a new microhabitat for species that occur in Uca burrows (Bright \& Hogue, 1972).

Studies are underway to determine the nature of the link between claw removal, subsequent behavioural disruption and changes in population size (see Fig. 1).

The claw exploitation of fiddler crabs may be a more general problem in crustacean fisheries. In at least two other species, stone crabs (Menippe mercenaria) in Florida (Savage \& Sullivan, 1978) and edible crabs (Cancer pagurus) in the North Sea (Jens Hoeg, pers. comm.), claws are exploited and clawless males are then released on their habitats. The consequences of this type of fishery in which the individuals are not removed from the population but the population structure is potentially affected have yet to be investigated. 


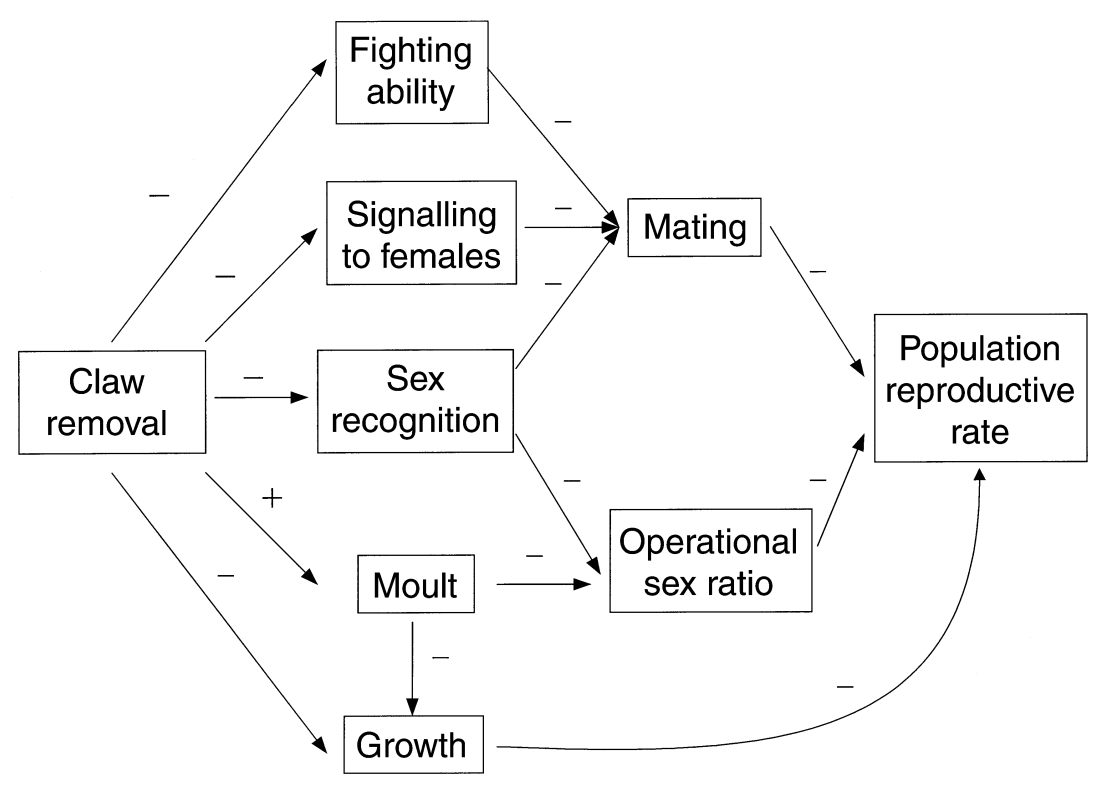

Fig.1. Causal model for the effect of claw harvesting on the population reproductive rate of fiddler crabs. Arrows indicate causal relationships supported by the available literature (see the text for details).

\section{Acknowledgements}

We thank Ria Formosa Natural Park, Portugal, and especially its Director Professor Luis Fonseca, for permission to work in their protected area and for logistic support. This study is part of a research project supported by the Instituto para a Conservação da Natureza/ Parque Natural da Ria Formosa (Convénio Pescas-Ambiente). We thank Alexandra Lopes for valuable help during data collection in the field. Colleagues in ISPA, Lisboa and the Behaviour Group, Copenhagen, also provided diverse support at all stages of the study.

\section{REFERENCES}

Ahmed, M. (1976). A study of the normal and aberrant sexual types of the Venezuelan fiddler crabs Uca cumulanta and $U$. rapax. Bull. Mar. Sci. 26: 499-505.

Andrade, F. (1986). O estuário do Mira: caracterização geral e análise quantitativa da estrutura dos macropovoamentos bentónicos. PhD. thesis: University of Lisboa, Lisboa.

Backwell, P. R. Y. \& Passmore, N. I. (1996). Time constraints and multiple choice criteria in the sampling behaviour and mate choice of the fiddler crab Uca annulipes. Behav. Ecol. Sociobiol. 38: 407-416.

Bildstein, K. L., McDowell, S. G. \& Brisbin, I. L. (1989). Consequences of sexual dimorphism in sand fiddler crabs, Uca pugilator: differential vulnerability to avian predation. Anim. Behav. 37: 133-139.

Bright, D. B. \& Hogue, C. L. (1972). A synopsis of the burrowing land crabs of the world and list of their arthropod symbionts and burrow associates. Contr. Sci. 220: 1-58.

Christy, J. H. \& Salmon, M. (1984). Ecology and evolution of mating systems of fiddler crabs (genus Uca). Biol. Rev. 59: 483-509.

Clutton-Brock, T. H. \& Parker, G. A. (1992). Potential reproductive rates and the operation of sexual selection. Quart. Rev. Biol. 67: 437-456.
Crane, J. (1975). Fiddler crabs of the world (Ocypodidae: genus Uca). Princeton: Princeton University Press.

Davis, G. E., Barghman, D. S., Chapman, J. D., MacArthur, D. \& Pierce, A. C. (1978). Mortality associated with declawing stone crabs, Menippe mercenaria. S. Florida Res. Cent. Rep. T522: 1-23.

Emlen, S. T. \& Oring, L. W. (1977). Ecology, sexual selection, and the evolution of mating systems. Science 197: 215-223.

Faria, M. M. (1994). A luta e o dimorfismo masculino nos caranguejos-violinistas Uca tangeri (Eydoux), (Ocypodidae, Brachyura). In Biologia e comportamento: actas do I congresso nacional de etologia: 127-136. Almada, V. C. \& Oliveira, R. F. (Eds). Lisboa: ISPA.

Greenspan, B. N. (1980). Male size and reproductive success in the communal courtship system of the fiddler crab Uca rapax. Anim. Behav. 28: 387-312.

Jennions, M. D. \& Backwell, P. R. Y. (1996). Residency and size affect fight duration and outcome in the fiddler crab Uca annulipes. Biol. J. Linn. Soc. 57: 293-306.

Juanes, F. \& Smith, L. D. (1995). The ecological consequences of limb damage and loss in decapod crustaceans: a review and prospectus. J. Expt. Mar. Biol. Ecol. 193: 197-223.

Katz, L. C. (1980). Effects of burrowing by the fiddler crab, Uca pugnax (Smith). Estuar. Coast. Mar. Sci. 2: 233-237.

Lourenço, R. M. (1995). Aspectos eco-etológicos de Uca tangeri, Eydoux (Crustacea: Ocypodidae) no sapal de Cacela Velha (Ria Formosa). Graduation thesis: University of Lisboa, Lisboa.

Montague, C. L. (1982). The influence of fiddler crab burrows and burrowing on metabolic processes in salt marsh sediments. In Estuarine Comparisons: 283-301. Kennedy, V. S. (Ed.). New York: Academic Press.

Oliveira, R. F. \& Custódio, M. R. (1998). Claw size, waving display and female choice in the European fiddler crab, Uca tangeri. Ethol. Ecol. Evol. 10: 241-251.

Oliveira, R. F., McGregor, P. K., Burford, F. R. L., Custódio, M. R. \& Latruffe, C. (1998). Functions of mudballing behaviour in the European fiddler crab Uca tangeri. Anim. Behav. 55: 1299-1309.

Ringold, P. (1979). Burrowing, root mat density, and the distrib- 
ution of fiddler crabs in the eastern United States. J. Expt. Mar. Biol. Ecol. 36: 11-21.

Rozenberg, M. S. (1997). Evolution of shape differences between the major and the minor chelipeds of Uca pugnax (Decapoda: Ocypodidae). J. Crust. Biol. 17: 52-59.

Salmon, M. \& Stout, F. (1962). Sexual discrimination and sound production in Uca pugilator Bosc. Zoologica 47: 15-21.

Savage, T. \& Sullivan, J. R. (1978). Growth and regeneration of the stone crab Menippe mercenaria. Florida Mar. Res. Publ. 32: $1-23$.

Skinner, D. M. (1985). Molting and regeneration. In Biology of Crustacea, vol. 9: 43-146. Bliss, D. E. \& Mantel, L. H. (Eds). New York: Academic Press.

StatSoft (1995). STATISTICA for Windows. (Computer program manual). Tulsa, OK: Statsoft, Inc.
Valiela, I., Babiec, D. F., Atherton, W., Seitzinger, S. \& Krebs, C. (1974). Some consequences of sexual dimorphism: feeding in male and female fiddler crabs, Uca pugnax (Smith). Biol. Bull. 147: $652-660$.

von Hagen, H. O. (1962). Freilandstudien zur sexual- und Fortpflanszungsbiologie von Uca tangeri in Andalusien). Zeit. Morphol. Ökol. Tiere 51: 611-725.

Wolf, P. L., Shanholtzer, S. F. \& Reimold, R. J. (1975). Population estimates for Uca pugnax (Smith, 1870) on the Duplin Estuary marsh, Georgia, USA (Decapoda, Brachyura, Ocypodidae). Crustaceana 29: 79-91.

Wolfrath, B. (1992). Burrowing of the fiddler crab Uca tangeri in the Ria Formosa in Portugal and its influence on sediment structure. Mar. Ecol. Prog. Ser. 85: 237-243. 